\title{
A Public and Private Dutch West India Interest
}

\author{
Henk den Heijer
}

\section{Introduction}

In the historiography, the term West India interest stands for a group of British stakeholders in the plantation economy in the Caribbean. That group emerged in the eighteenth century, and its objective was to forcefully defend the West Indian interests of the members in the British parliament. In her 1921 article "The London West India Interest in the Eighteenth Century," Lilian Penson distinguished three London-based interest groups that decided to work together: agents from the West Indian colonies, merchants who traded with the colonies, and plantation owners who lived in the city. She describes how various stakeholders formed an effective lobby group after a successful campaign for the introduction of the Molasses Act in 1733. This lobby group managed to keep foreign plantation products from the British market via the parliament. ${ }^{1}$ The image of a powerful, homogenous interest group was recently adjusted by Andrew O'Shaugnessy. ${ }^{2}$ He demonstrated that the lobby was initially a fairly informally organized economic interest group, able to apply political pressure during the American Revolution, but that it also suffered from internal dissension. The interests of the group began to diverge more and more at the end of the eighteenth century. Nevertheless there was a lobby in Great Britain that managed to get the West Indian interest on the parliamentary agenda. Did the Dutch Republic have such an interest group, as well? Not according to J.P. van de Voort. In his dissertation on the West Indian plantation loans, he states that it was impossible for a Dutch West India interest to emerge, since the interests of such a pressure group were incompatible with the principles of an open staple market. A monopoly supply of plantation products from the colonies such as in Great Britain was unthinkable in the Republic, simply because the Dutch colonies could not meet the growing demand for sugar, coffee and other colonial products. Import from non-Dutch areas was necessary. ${ }^{3}$

\footnotetext{
* I would like to thank Dave Boone and Gerhard de Kok who did a part of the archival research for this article.

1 L.M. Penson, "The London West India Interest in the Eighteenth Century," English Historical Review 30 (July 1921): 373-392, 374.

2 A.J. O'Shaugnessy, "The Formation of a Commercial Lobby: The West India Interest, British Colonial Policy and the American Revolution," Historical Journal 40 (1997): 71-95.

3 J.P. van de Voort, De Westindische plantages van 1720 tot 1795. Financiën en handel (Eindhoven: De Witte, 1973), 27.
}

(C) HENK DEN HEIJER, 2014 | DOI 10.1163/9789004271319_009

This is an open access chapter distributed under the terms of the Creative Commons 
The key question in this chapter is whether or not the Republic had some sort of West India interest. Of course there have been individuals as well as organizations with West Indian interests, but around which subjects were they organized? Did these individuals and various groups collaborate and, if so, did that collaboration have similarities with that in Great Britain? A parallel seems hard to draw in advance; the significantly different state structure of the Republic will have affected the interests of various groups. The fragmented governance structure that was so characteristic to the Republic did not exist in Great Britain. ${ }^{4}$ This chapter begins with the West Indian interests of the central government and then discusses the conflicts of interest between the provinces of Holland and Zeeland. Afterwards, we will shed light on how interest groups emerged at a local level in the Republic and how they defended their interests. Finally, we will discuss the alleged differences between the Republic and Great Britain and the role the States General played in balancing the different Atlantic interests in the Republic.

\section{Private Interest as State Interest}

At the beginning of the seventeenth century, the economic interests of Dutch merchants in the Atlantic were still modest. During the initial phase, the Republic had few to no planters overseas, nor sugar refiners at home. In 1609 a group of merchants submitted a petition to the States General for the first time, requesting protection of their trade interests in West Africa. ${ }^{5}$ The reason for this was that their ships were continuously being attacked by the Portuguese. Around 160o, however, it was not private interests but rather government interests of a military nature that rapidly sucked the Dutch into the Atlantic. The States General had been making efforts to relocate the battle against Spain from land to sea and from Europe to regions outside of Europe since the end of the sixteenth century. It was mainly the Spanish and Portuguese colonies in

4 Not only the government but also private organizations with interests overseas had decentralized governance structures. The Dutch West India Company (WIC), for instance, had a so-called chamber structure which reflected the economic and political hierarchy of several towns within the Dutch Republic. H. den Heijer, Geschiedenis van de WIс. Opkomst, bloei en ondergang (Zutphen: Walburg Pers, 2013), 27.

5 J.K.J. de Jonge, De oorsprong van Neerland's bezittingen op de kust van Guinea, in herinnering gebracht uit de oorspronkelijke stukken, naar aanleiding van een voorgenomen afstand dier bezittingen aan Groot-Brittannië ('s-Gravenhage: Martinus Nijhoff, 1871), 33-39. 
the Atlantic that generated the capital with which the battle against the Republic was funded, and these territories, therefore, formed interesting targets for the Dutch. However, the government had no financial resources to fight this battle on its own, and resorted to private investors at a very early stage. The enormous war fleet of Pieter van der Does that carried out attacks on the Canary Islands and São Tomé in 1599 was such a public-private enterprise, whose main objective was military in nature. Eventually, this joint venture culminated in the establishment of the West India Company (WIC) in 1621, a private company with commercial and military goals. The charter of the Company stated that, in case of war overseas, it could count on financial and material support from the government. ${ }^{6}$ In the first half of the seventeenth century, during which the wIC unsuccessfully attempted to build an Atlantic empire, the States General provided support by means of money, war ships and troops several times.

After the end of the Revolt against Spain in 1648, there was no reason to continue the battle in the Atlantic. Meanwhile, the economic interests of the Dutch in the Atlantic had increased significantly. Colonies had been established and the supply and processing of, and trade in, plantation products such as sugar and tobacco became increasingly important for the Dutch economy. This also significantly changed the nature of the Atlantic interest of the government. From the mid-seventeenth century until the end of the eighteenth century, the roles were reversed and the military actions in the Atlantic were primarily in the service of the economic interests of private organizations. For instance, the States General sent Michiel de Ruyter to West Africa in 1664 to recapture the wIC forts, which had previously been captured by the English. The expedition of Abraham Crijnssen to the West Indies organized in 1667 by the Admiralty of Zeeland, and in which Crijnssen captured Suriname, fit in this policy as well. The trade in, and processing of, plantation products had become too important to the Republic not to defend. In addition to profit for merchants, sugar, tobacco and other products also provided employment. After all, almost all Atlantic products had to be processed, which created many jobs. Amsterdam and Rotterdam had dozens of sugar refineries and tobacco mills within their walls. For the survival of these companies, not to mention to ensure their continued success, the supply of raw materials from the Atlantic was essential. After the WIC had been forced to give up its imperial ambitions with the loss of Brazil in 1654, the Company had the task of managing

6 Octroy, by de Hooge Mogende Heeren Staten Generael, verleent aende West-Indische Compaignie in date den derden Juni 1621 ('s-Gravenhage: Hillebrant Jacobssz, 1621), articles 11-12. 
the remaining infrastructure in the Atlantic, allowing production and trade to be continued. When the Company threatened to collapse under the burden of debt in 1674, the States General decided to reorganize the Company financially, allowing it to restart. ${ }^{7}$ It was simply unthinkable for the government, with its limited resources, to manage these overseas possessions itself.

In addition to the WIC, there were other private organizations that managed Dutch possessions in the Atlantic. They were established with the permission of - and sometimes even initiated by - the government. That is how, in the 1620 s, private colonies emerged under so-called patroonships. ${ }^{8}$ Most of these organizations existed only briefly, but some of them had a longer lifespan, such as Tobago, which was a patroonship with alternating owners between 1628 until $1677 \cdot{ }^{9}$ In 1683 , the Society of Suriname had been established, in which the wIC, the city of Amsterdam and the Van Sommelsdijk family each owned a third. Both societies had been granted a patent by the States General, which not only granted rights to these individual organizations, but also required them to protect the possessions of the societies in times of trouble. Eventually the WIC, the patroonships and the societies were mandated by the government to rule overseas regions and to run the judicial system there on its behalf. On paper, however, the States General were ultimately responsible for the governance, the application of the judicial system and the safety of the colonies. ${ }^{10}$ For these individual organizations, this was a reason to turn to the government for military support when needed. The wIC even had a so-called "Haags Besogne," a semi-permanent consultative body of directors and delegates of the States General, to exchange information and represent their interests. ${ }^{11}$ The fact that the government had an

$7 \quad$ H. den Heijer, Goud, ivoor en slaven. Scheepvaart en handel van de Tweede Westindische Compagnie op Afrika, 1674-1740 (Zutphen: Walburg Pers, 1997), 39-49.

G.J. van Grol, De grondpolitiek in het West-Indische domein der Generaliteit, two parts in one volume (Amsterdam: Emmering, 1980), 2:24-25.

Another example is the plantation colony of Berbice. The Zeeland merchant Abraham van Pere had established this colony on the Coast of Guiana in 1627 with the permission of the WIC and the States General. Until the beginning of the eighteenth century, this colony was owned by the Van Pere family. After the French privateer Jacques Cassard plundered the colony, the family was forced to sell Berbice to a group of Amsterdam merchants in 1714, who converted the ownership and governance of the plantation colony into the share-funded Society of Berbice in 1720.

10 The States General was the sovereign body of the Republic, but private organizations like the WIC and the societies had suzerain power over the colonies.

11 Den Heijer, Goud, ivoor en slaven, 51. 
interest in the preservation of individual Atlantic organizations was evidenced by the fact that government support was frequently granted. For instance, in 1674, the WIC received a guarantee from the States General that it would pay the costs for 200 soldiers every year, an amount that was allocated to all provinces via the then current repartition system. ${ }^{12}$ The patroonships and societies could count on support as well. The Society of Suriname was given access to state army troops twice in the eighteenth century, for the purpose of disabling the maroons in the colony. And in Berbice, State troops were deployed in 1764 to put an end to the slave revolt that was threatening the existence of the colony.

It would be incorrect to assume that the fragmented government of the Republic granted support to Atlantic organizations without conditions. Even within the States General, there were significant conflicts of interest between the sea and land provinces. The latter had fewer economic ties with the Atlantic than the sea provinces of Holland and Zeeland and often had a negative attitude towards supporting the WIC or the West Indian colonies. Representatives of the States of Holland and Zeeland often had to exert pressure on the land provinces to get financial support for the West Indian colonies. In addition, the States General required the Atlantic organizations to make significant financial contributions to keep the defense and the administration of their colonies up-to-date. But these organizations passed on the costs to the colonists to a large degree, resulting in protests and resistance. In Suriname and all other Dutch colonies in the West, conflicts between the government and the colonists about the payment for fortifications and troops led to a neglect of the defense of these territories. That neglect caused a fierce battle in the Patriot era about the governance and the defense of the Atlantic colonies. ${ }^{13}$ After the Fourth Anglo-Dutch War (1780-1784) and the temporary elimination of the

12 Octroy, by de Hoogh Mogende Heeren Staten Generael, verleent aen de West-Indische Compagnie in date den twintighsten september sesthien hondert vier en tseventigh ('s-Gravenhage: Jacobus Scheltus, 1674), Article 39. Under the repartition system the costs of the States General were distributed among the provinces according to their ability to pay. In practice, Holland, the most prosperous province of the Republic, paid half of the subsidy. Initially, the wIC got a subsidy commitment for eight years, but, in practice, the subsidy was paid until the liquidation of the Company in 1791. National Archives of the Netherlands, The Hague, (hereafter NL-HaNA), Tweede West-Indische Compagnie (NWIC), 1.05.01.02, inv. nos. 268-271.

13 G.J. Schutte, De Nederlandse Patriotten en de koloniën. Een onderzoek naar hun denkbeelden en optreden, 1770-180o (Groningen: Tjeenk Willink, 1974), 54-59. The Patriots were political newcomers without influence who wanted to reform the government. They revolted against the conservative Orangists, the ruling class who supported the Stadtholder. 
Patriots, the States General sent two representatives, W.A.J. Grovestins and W.C. Boeij, to the West to put things in order. ${ }^{14}$ Despite the tension that existed between the provinces, the States General, the Atlantic organizations and the colonies, there were always forms of collaboration that assured continuity, however unstable it sometimes may have been. It was not until the end of the eighteenth century, when the fragmented governance system in the Republic started to become unworkable, that the state took over the colonies and the private Atlantic organizations were eliminated.

The wIC and the societies were not the only ones who lobbied the States General for military protection. Groups of merchants did the same. A minority of the merchants was involved in the trade with Guiana but the majority had commercial ties with the Caribbean islands which were the sites of the most important trade of the entire Atlantic region. Via Curaçao and St. Eustatius, more tropical products of the English, French and Spanish colonies were shipped to the Republic than from the Dutch plantation colonies in Guiana. When the trade with the islands was threatened during the War of the Austrian Succession (17401748), groups of merchants from Amsterdam and Rotterdam launched actions to defend their interests. The Republic was officially neutral in the war, but treaties with Austria and Great Britain forced the States General to deploy state troops against the French in the Southern Netherlands in 1745. That development posed a serious threat to the Caribbean trade for several reasons.

For instance, the States General decided in 1747 that a third of the crew of merchant vessels had to serve on the war fleet that was to protect Dutch merchantmen from the attacks of the French navy in European waters..$^{15}$ That measure would seriously hamper Dutch intercontinental shipping and trade. That is why the directors of the Society of Suriname and Berbice protested, after which the States General exempted navigation to and from Guiana from this measure. ${ }^{16}$ Merchants who traded with the Caribbean islands also joined forces and approached the States General via the directors of the wIC with the request to revoke these harmful measures for Caribbean shipping. The joint protest of the merchants was successful; the States General also exempted ships engaged in Caribbean navigation from providing crewmembers to the war fleet. ${ }^{17}$

\footnotetext{
14 Ibid., 92.

15 I. Scheltus, ed., Groot Placaatboek, vervattende de placaaten (...) van de Staaten Generaal (...), 9 vols. ('-Gravenhage: Isaac Scheltus, 1779), 7:511, Placard 12 June 1747.

16 Ibid., 514, Placards 18 July and 3 August 1747.

17 NL-HaNA, WIC, 1.05.01.02, inv. no. 451, Gentlemen Ten to States General, 9 September 1747. Scheltus, Groot Placaatboek, 7:511, Placard 12 June 1747.
} 
More harmful than this obligation to provide crew members was the measure that prohibited trade with France and her colonies. ${ }^{18}$ Amsterdam and Rotterdam merchants who imported sugar and coffee via French ports were willing to accept this ban, but they refused to accept an import ban on French sugar via Curaçao and St. Eustatius. The latter would mean the end of their Atlantic trade. In a coordinated action, merchants and insurers from Amsterdam and Rotterdam submitted petitions to the States General to eliminate the ban that would "ruin the overall Dutch trade with the West." These petitions were signed by 185 merchants, including influential regents with Atlantic trade interests. ${ }^{19}$ This led to the decision of the States General to scale back the measure. Ships that were en route from the Caribbean with French products were given free admission to Dutch ports. ${ }^{20}$

Another issue for which the help of the government was asked was the protection of West Indiamen. Ships that sailed to the Caribbean were frequently the victims of privateers, despite the neutrality policy of the Republic during a large part of the eighteenth century. In the 1730s, the Spanish navy captured several Dutch merchantmen in the Caribbean on suspicion of smuggling to the Spanish colonies. At the instigation of the WIC, the Admiralty of Amsterdam sent one or two convoys to the West Indies per year after 1737 to protect merchants from Spanish confiscations. ${ }^{21}$ But soon the convoy system was discarded by the Admiralty, despite protests from merchants who emphasized that - even without the threat of Spanish warships - the Caribbean Sea was a perfect area for privateers who did not stick to the rules and resorted to piracy. Ships carrying valuable loads of Atlantic products were appealing prey to them. In 1745, Amsterdam merchants submitted two petitions to the States General in which they requested protection against privateers. To the second petition, which was signed by 110 merchants, a list of $3^{2}$ ships was added that had been confiscated by English and Spanish privateers. The merchants were supported by the Board of the wIC, which was not able to offer sufficient protection. ${ }^{22}$ The States General took the petitions seriously, and commissioned

18 Scheltus, Groot Placaatboek, 7:499-503, Placard 5 December 1747.

19 NL-HaNA, Staten-Generaal, 1.01.02, inv. no. 7809, Petitions 3 January 1748. Well-known regents like Thomas and Adriaan Hope, Abraham van Hoboken and Jacob and Adriaen Temminck were among the signatories.

20 Scheltus, Groot Placaatboek, Vol. 7, 504-505, Resolution 29 January 1748.

21 J.R. Bruijn, De admiraliteit van Amsterdam in rustige jaren, 1713-1751. Regenten en financiën, schepen en zeevarenden (Amsterdam/Haarlem: Scheltema \& Holkema, 1970), 24-25.

22 NL-HaNA, Staten-Generaal, 1.01.02, inv. no. 380o, Resolution 28 June 1745; NL-HaNA, Staten-Generaal, 1.01.02, inv. no. 780o, Petition 8 October 1748; NL-HaNA, Staten-Generaal, 1.01.02, inv. no. 3801, Resolution 16 April 1746 . 
the Admiralty of Amsterdam to restart the convoying of the West Indiamen. When, after several new ships were captured by privateers, it turned out that the frequency and effectiveness of convoying left much to be desired, the stakeholders proposed to the States General that an armed convoy to the West Indies be organized twice a year.

The States General granted that request in December 1747 "to indemnify the subjects of the State for damage with all resources possible." ${ }^{23}$ However, the convoy system fell apart once again due to the costs the Admiralty of Amsterdam had to incur to maintain it. During the Seven Years' War (17561763) large groups of merchants were continuously bombarding the States General with petitions for the improvement of the convoy system, with varying degrees of success. In June 1758, the representatives of the States General, in an action that was very likely coordinated, received six petitions signed by no fewer than 650 merchants from several cities in the Republic. ${ }^{24}$ All these petitions demonstrate that merchants were continuously working together to defend their West Indian trade interests via the States General. The States General, in turn, was usually willing to grant these requests; after all, they also had an interest in the continuity of Atlantic shipping and trade, even if the financial resources they could provide were limited.

\section{Conflicting Interests: Monopoly versus Free Trade}

Based on enlightened self-interest, the States General supported various private organizations and merchants who were active in the Atlantic region. Only then could the economic interests of the country best be served. However, the problem was that the Atlantic interests of the provinces and cities in the States General could differ significantly. These diverging interests led to a fierce conflict of interest between Zeeland and Holland several times. The Zeeland merchants lost more and more ground to Holland, and, particularly, to Amsterdam, in European shipping and trade over the course of the seventeenth century and wanted to make sure that the same would not happen in the Atlantic. An important point of conflict, which both parties tried to settle in varying ways within and outside the States General, was the question of whether or not the trade monopoly of the WIC should be preserved in certain parts of its mandate area.

23 NL-HaNA, Staten-Generaal, 1.01.02, inv. no. 3802, Resolutions 26 October and 1 December 1747.

24 NL-HaNA, Staten-Generaal, 1.01.02, inv. no. 7848, Petitions of merchants, 1 June 1758. 
Initially, the Zeelanders were in favor of preservation of the Company monopoly, which guaranteed them that a portion of the Atlantic trade would remain in Zeeland's hands. ${ }^{25}$ The first test case was the Dutch colony in Brazil. Almost immediately after the occupation of Recife in 1630, Amsterdam merchants fought for free trade with Brazil, which was the most important sugar producing region in the world. Amsterdam had growing interests in sugar refining and the sugar trade and aimed to acquire the largest possible share of the available sugar. The battle that erupted within the wic between Amsterdam and Zeeland about the opening up of the sugar trade was temporarily won by Amsterdam in the fall of 1630 . The States General allowed free trade, provided that all goods were shipped from and to Brazil using Company ships and the WIC would receive a fee and shipping costs. In 1634, the rules on free trade were loosened which allowed the Amsterdam merchants to gain control over a large portion of the sugar trade. ${ }^{26}$ The timing was not coincidental, since at that moment the power of the Company in Northeast Brazil had increased significantly and the colony began to produce more sugar. In its wake, the battle about monopoly versus free trade flared as well. Supporters and opponents of the monopoly published dozens of pamphlets in which they tried to sway public opinion of the reasonableness of their views. ${ }^{27}$

In 1636, resistance against free trade grew, including within the Company, and the directors of the Chamber of Zeeland were able to stir up resistance against Amsterdam. Eventually, in late December 1636, the States General decided to restore the Company monopoly and free trade was banned immediately. ${ }^{28}$ It seemed that Zeeland had won the battle, but this victory was only a mirage. A publicity offensive was launched against the reinstatement of the monopoly by Amsterdam. In addition, Amsterdam also applied political pressure within the States of Holland and the States General. From Dutch Brazil, the merchants of Amsterdam were supported by no less than

25 Zeeland had a 2/9 share in the wIC, which determined that $2 / 9$ of the shipping and trade of the company was done by the Chamber of Zeeland.

26 Articulen (...) over het open ende vry stellen van den handel en negotie op de stadt Olinda de Pernambuco, ende custen van Brasil (Amsterdam: Paulus Aertsz van Ravesteyn, 1630); C.R. Boxer, The Dutch in Brazil, 1624-1654 (Oxford: Clarendon, 1957), 75-76.

27 G.M. Asher, A Bibliographical and Historical Essay on the Dutch Books and Pamphlets Relating to New Netherland and to the Dutch West-India Company and its Possessions in Brazil, Angola etc. (Amsterdam: Israel, 1966), 135-138; H. den Heijer, "Het recht van de sterkste in de polder. Politieke en economische strijd tussen Amsterdam en Zeeland over de kwestie Brazilië, 1630-1654," in Harmonie in Holland. Het poldermodel van 1500 tot $\mathrm{nu}$, ed. D. Bos, M. Ebben and H. te Velde (Amsterdam: Bert Bakker, 2007), 79-84. 
Governor-General Johan Maurits van Nassau-Siegen, who was convinced that the colony would only be able to flourish with free trade. ${ }^{29}$ After a year-long battle between Zeeland and Amsterdam, the States General decided on 29 April 1638 to partially dismantle the monopoly of the Company for the second time. ${ }^{30}$ Only the slave trade remained a privilege of the wic. With this decision, the ban on individual trade initiated by Zeeland in 1636 turned out to be a Pyrrhic victory. The West Indian interests of Holland, in particular of the economically strong Amsterdam, carried more political weight and would eventually be the decisive factor in the free trade debate. ${ }^{31}$

After the loss of Brazil in 1654, conflicts between the provinces of Zeeland and Holland about shipping and trade in the Atlantic kept arising. In the late 1720s, those conflicts would once again lead to a fierce battle between Amsterdam and Zeeland. However, this time the roles were reversed and the directors of the Chamber of Amsterdam defended the last monopoly of the Company: the trade and shipping to West Africa and the associated slave trade in the Dutch colonies in America. The reason for the conflict was the illegal commodity and slave trade of the Zeelanders in West Africa. In response to the structural loss of trade activities within Europe to merchants in Holland, the Zeelanders had focused on risky shipping branches such as privateering and smuggling, activities the merchants of Holland hardly engaged in. Privateering by Zeelanders was done in times of war and smuggling in times of peace. ${ }^{32}$ Zeeland interlopers who dispatched ships to Africa always ran the risk of having their ships captured and confiscated by the wIC. That is why the Council of Middelburg was already urging the abolition of the Company's trade monopoly with West Africa in 1692. The directors of the WIC unanimously rejected

29 A. Bick, Governing the Free Sea: the Dutch West India Company and Commercial Politics, 1618-1645 (unpublished PhD diss., Princeton University, 2012), 200-204.

3o Reglement byde West-Indische Compagnie (...) over het open-stellen vanden handel op Brazil ('s-Gravenhage: Jacobssz van Wouw, 1638).

31 Den Heijer, "Het recht van de sterkste," 72-92.

32 Privateering activities are researched by F. Binder, "Die Zeeländische Kaperfahrt, 1654-1662," in Archief. Mededelingen van het Koninklijk Zeeuwsch Genootschap der Wetenschappen (1976), 40-92, J. Francke, Utiliteyt voor de gemeene saake. De Zeeuwse commissievaart en haar achterban tijdens de Negenjarige Oorlog, 1688-1697 (Middelburg: Koninklijk Zeeuws Genootschap der Wetenschappen, 2001) and J.Th.H. Verhees-van Meer, De Zeeuwse kaapvaart tijdens de Spaanse Successieoorlog, 1702-1713 (Middelburg: Koninklijk Zeeuws Genootschap der Wetenschappen, 1986), while smuggling is researched by R. Paesie, Lorrendrayen op Africa. De illegale goederen- en slavenhandel op West-Afrika tijdens het achttiende-eeuwse handelsmonopolie van de West-Indische Compagnie, 1700-1734 (Amsterdam: De Bataafsche Leeuw, 2008). 
Middelburg's proposal, and there were no changes in the monopoly. ${ }^{33}$ Meanwhile, the organized illegal slave and commodity trade from Zeeland continued, in particular when, after the end of the War of the Spanish Succession (1702-1713), privateering disappeared as a major source of income.

In 1716 Zeeland once again submitted a request to open up trade to West Africa. They referred to England as an example, where the Parliament had opened up the trade to West Africa in 1698. That decision had significantly boosted English trade in West Africa, including the slave trade. However, the directors of the Company did not like the proposal and unanimously rejected it, so illegal trade continued. In the years after the War of the Spanish Succession, not only did smuggling activities increase, but due to stricter inspections in West Africa, many Zeeland smuggling ships were confiscated as well. Between 1714 and 1725, 27 Zeeland interlopers were captured by Company cruisers, and the commerce of the province suffered over 1.7 million guilders in damages. ${ }^{34}$ The West Indian interest of the Zeelanders was seriously threatened by the actions of the Company. Therefore, it is not surprising that it was the merchants of Zeeland who developed initiatives to dismantle the last monopoly of the wic.

Several years before the States General had to decide on the renewal of the charter of the Company in 1730, the Zeelanders launched their attack on the monopoly. In the fall of 1727 , a group of merchants from Vlissingen drafted a notice of objection, urging the full freeing up of the Atlantic trade. The merchants believed that the monopoly was seriously damaging the Dutch economy, since the WIC was not able to adequately conduct the commodity trade in West Africa, nor could it manage the slave trade. They estimated that, after the dissolution of the last Company monopoly, 50 ships a year would be dispatched from Zeeland to West Africa, including ships deployed for the slave trade. ${ }^{35}$ The merchants of Vlissingen received support from a group of merchants from Middelburg, who established an almost identical proposal for liberalization of the trade. Both proposals were merged into one document by representatives of the City Councils of Middelburg and Vlissingen in 1728 and submitted to the States of Zeeland. ${ }^{36}$

After receipt of the document, the States of Zeeland appointed a committee that was to further develop the proposal to dismantle the Company monopoly

33 NL-HaNA, WIC, 1.05.01.02, inv. no. 656, Minutes 29 September 1692.

34 NL-HaNA, Radermacher, 1.10.69, inv. no. 596. List of ships from Zeeland confiscated by the WIC.

35 NL-HaNA, Verspreide West-Indische Stukken, 1.05.06, inv. no. 904. Short account.

36 Zeeuws Archief (ZA), Archief Staten van Zeeland (SvZ) 325, Resolution 30 November 1728. 
in the States General. The Zeeland plan to change the charter would soon also be known in Amsterdam. It immediately provoked a counter attack for the preservation of the monopoly. Directors of the Amsterdam Chamber believed that opening up trade in West Africa would mean the fall of the wIC. The tax income would be insufficient to cover the costs of forts and factories. ${ }^{37}$ Moreover, the Amsterdam directors did not trust the Zeeland stakeholders in the Atlantic trade. They had partaken in smuggling activities on a large scale and would not shy away from evading tax on the trade in Africa in the future as well. It was clear that Zeeland and Amsterdam could not disagree more regarding a possible change of the Company charter. The battle between the two parties would be fought in both the WIC and the States General, which eventually had to renew the charter.

The Zeeland directors were now openly backing the proposals of the merchants from their province. Together with the other Zeeland stakeholders in the Atlantic trade, they convinced the States of Zeeland to forcefully defend the dismantling of the monopoly in the States General. In an unexpected turn of events, the people of Zeeland received support from a group of plantation owners in Suriname who urged the States General to open up the slave trade in the colony. They said that the WIC was not able to provide a sufficient number of Africans to the colony, so there was a chronic lack of slaves. ${ }^{38}$ Under pressure from all those protests, Amsterdam agreed to change the mandate, but with a number of limitations on free trade. On 8 August 1730, the States General approved the changed charter for a period of 30 years. According to the charter, the Company would have a 6o-mile strip on the Gold Coast as an exclusive trade area, exactly the area that contained its forts. In addition, the WIC retained the monopoly on the slave trade in the Dutch plantation colonies in Guiana. ${ }^{39}$ The renewed charter was a typical compromise product, against which the Zeeland merchants would immediately object. Once again, they were able to get the States of Zeeland to undertake action in the States General, due to which the charter was modified in 1734. The exclusive 6o-mile zone was now also opened up to individuals. Only the slave trade in Guiana remained exclusive to the wIC, but it would eventually waive this right

37 ZA, Recueils van Citters (RvC) 105, Recueil L, Directors of Amsterdam to Directors of Zeeland, 11 February 1729.

38 NL-HaNA, Verspreide West-Indische Stukken, 1.05.06, inv. no. 904. Petition of Suriname planters to the States General.

39 Nader Prolongatie van het Octroi voor de Westindische Compagnie en van de eerste prolongatie van dien, voor den tyd van nog dertig jaaren. Gearresteert den 8 Augusti 1730 ('s-Gravenhage: Jacobus Scheltus, 1730), Article 19. 
voluntarily in 1738 . Several unfortunate slave journeys that had led to significant losses due to a high death rate, as well as decreasing slave prices, led the Board of the Company to decide to retreat from the slave trade. ${ }^{40}$ The Zeelanders had won the battle with Amsterdam, and became the most important Dutch slave traders in the Atlantic from the 173 os onwards.

After the battle for the dissolution of the last trade monopoly had been settled, a new conflict arose. The third major conflict that the States General settled between both regions concerning Atlantic interests was about trade with, and shipping to, the plantation colonies Essequibo and Demerara. In this case, it was the Zeelanders who defended their privileges. Demerara was established in 1745 as a part of Essequibo and had been ruled from there ever since. Both colonies fell under the charter of the WIC but were managed by the Zeeland Chamber. The Zeelanders, who had founded Essequibo in 1616, claimed the exclusive right to trade in the region. As long as the plantation production was limited, nobody objected to the self-proclaimed monopoly of the Zeelanders. However, this changed when the colony grew and the demand for colonial products in the Republic increased. Around the mid-eighteenth century, opposition against the de facto Zeeland monopoly grew in Holland. Incidentally, the complaints did not emerge in Holland first. Rather they emerged in the colony itself, where Governor Laurens Storm van 's Gravensande repeatedly complained to the Zeeland directors about the limited supply of commodities and slaves. ${ }^{41}$ This complaint was taken very seriously by the "Gentlemen Ten," the ruling Council of the wIC, and was translated into an appeal to the directors of all the chambers to stimulate the trade to Essequibo and Demerara. The Zeeland directors considered this appeal to be a violation of the Zeeland monopoly and protested against it, thus giving birth to the controversy around the shipping and trade on Essequibo and Demerara. ${ }^{42}$

The conflict about the Zeeland trade monopoly occurred in two phases. During the first phase, which lasted from 1750 until 1765 , the Zeelanders fought against the directors of the Amsterdam Chamber. Two weeks after the disputed decision of the Gentlemen Ten, the main shareholders of the Zeeland Chamber gathered to agree on a strategy for the preservation of the monopoly. They chose four representatives who were to defend their interests in various political forums. On behalf of the main shareholders, many of whom had interests in the trade with Guiana, a petition was submitted to the States General in late

\footnotetext{
40 Den Heijer, Goud, ivoor en slaven, 343-346.

41 J.A.J., Villiers, Storm van 's Gravensande zijn werk en zijn leven uit zijne brieven opgebouwd ('s-Gravenhage: Martinus Nijhoff, 1920), 17-18.

42 NL-HaNA, WIC, 1.05.01.02, inv. no. 12, Resolution Gentlemen Ten, 11 August 1750.
} 
August of 1750, who in turn forwarded the document to the Amsterdam Chamber for advice. The response of the Amsterdam directors was predictable. Through Willem Roëll and Thomas Hope, they stated that there had never been a Zeeland monopoly and therefore the claim of the main shareholders had to be rejected. Both directors told the States General that despite this rejection, Amsterdam was still willing to accommodate the Zeeland request if the Zeeland shareholders would compensate them for all costs incurred by the WIC for Essequibo in the past. ${ }^{43}$ But by the time this Amsterdam proposal had reached The Hague, the main shareholders in Zeeland had already asked the States of Zeeland for help, who, in turn, had ordered Governor Storm van 's Gravensande in Essequibo to only allow ships with a Zeeland license to the colony. ${ }^{44}$ Simultaneously, the main shareholders called on the City Council of Middelburg to fight for the preservation of the Zeeland monopoly. The result of the lobbying of the main shareholders was that the States General was repeatedly asked to preserve the Zeeland monopoly. In opposition to this, the Amsterdam directors kept urging the States of Holland and the States General to eliminate the de facto monopoly, unless the Zeelanders were willing to pay for it. ${ }^{45}$ The Zeeland representatives in the States General consequently rejected the latter proposal, and with that prevented a possible settlement of the conflict concerning Essequibo.

1765 marked the start of a new phase, which also involved merchants from outside the wIC. The Zeeland main shareholders, who had not been against a financial settlement during the first phase, reopened the Essequibo matter in May 1765 by starting negotiations with the Amsterdam directors of the Company about the purchase of the colony. These negotiations took place in The Hague under the supervision of the delegates of the States General. ${ }^{46}$ Just when a solution was within reach, a group of Dutch investors turned against the possible sale of Essequibo to Zeeland. In the 176os, they had given significant loans to planters in the colony, and demanded free navigation to Essequibo

43 NL-HaNA, Verspreide West-Indische Stukken, 1.05.06, inv. no. 1171, Petition of major shareholders Zeeland to States General, 31 August 1751; W. Roëll and Th. Hope to States General, 19 January 1751.

44 Verslag gedaan door Burgemeester en Wethouders van Middelburg aan den Raad dier Gemeente (Middelburg, 1898), 20.

45 Petitions of merchants and correspondence about the Zeeland monopoly can be found in NL-HaNA, Verspreide West-Indische Stukken, 1.05.06, inv. no. 1171. See also NL-HaNA, wIC, 1.05.01.02, inv. no. 451, Letters of Gentlemen Ten and Directors of Amsterdam to States General, 25 February 1755 and 10 March 1756.

46 NL-HaNA, wIC, 1.05.01.02, inv. no. 451, Gentlemen Ten and Directors of Amsterdam to States General, 25 September 1765 . 
and Demerara in return. In May 1768, they submitted a petition to the States General in which they insisted on the dismantling of the monopoly, which they believed to be illegal. Zeeland merchants, who feared that the colonial trade would eventually fall entirely into Amsterdam's hands, also submitted a petition to the States General, insisting on the continuation of the monopoly. ${ }^{47}$ As the Zeelanders and the Hollanders fought about their opposing colonial interests in the Republic via the States General, the supply issues in Essequibo and Demerara became worse. In September 1769, Storm van 's Gravesande drew up a petition with the Council of colonists, asking the States General to allow the slave trade with the English for the payment of a tax. That petition was signed by 71 planters and sent to the Republic with a letter of support by the governor. The merchants of Zeeland were furious about the petition and said that allowing the English would mean the fall of the Dutch slave trade, which was essential to the Zeelanders. ${ }^{48}$

The conflicting petitions of the merchants of Zeeland, Amsterdam and planters in the colony led to a stalemate in the States General. To force a breakthrough in the long-running conflict, the Stadtholder was involved in the matter as a referee. William $V$ was the supreme director of the WIC, but was represented on the Board of the Company by Ferdinand van Collen. Van Collen very likely played an important role in the establishment of a new scheme for the trade with the colonies, issued on 25 October 1770 by the governor. ${ }^{49}$ It was a typical compromise in which neither party was proved right. In the new scheme, the Zeeland monopoly was rejected, but to placate them the merchants of Zeeland were given the privilege of being the first to send 16 ships to Essequibo and Demerara each spring, after which the Hollanders were also allowed to participate in navigation to both colonies. Several months after the enforcement of the new scheme, a group of Middelburg merchants founded a shipping company for navigation to the colonies. It was the final attempt to keep dominating the trade with Essequibo and Demerara, but it wasn't a very successful one. The company suffered heavy losses during the Fourth

47 NL-HaNA, Staten-Generaal, 1.01.02, inv. no. 7886, Petition of merchants of the province of Holland, 6 May 1768; Ibid., Petition of merchants of the province of Zeeland, 26 August 1768.

48 NL-HaNA, Verspreide West-Indische Stukken, 1.05.06, inv. no. 1222, Letter by the WIC Directors of Zeeland to States General, 19 February 1770; Ibid., Petition of merchants of Middelburg and Vlissingen to States General, 21 March 1770.

49 NL-HaNA, Verspreide West-Indische Stukken, 1.05.06, inv. no.1204, Resolutions States General, States of Holland and other provinces about free shipping and trade on Essequibo and Demerara, 1770-1773. 
Anglo-Dutch War which lead to the elimination of the shipping company in $1788 .^{50}$ From 1770 onwards, the shipping activities of Amsterdam to Essequibo and Demerara increased, and Zeeland lost more and more ground. Amsterdam's preeminence did not last long, however, since in the Napoleonic Era both colonies were conquered by the British, never to be given back. ${ }^{51}$

Zeeland and Holland fought about the configuration of parts of the Atlantic shipping and trade within and outside of the existing political bodies in the Dutch Republic for a century and a half. That battle says a great deal about the interest both regions had in the Atlantic trade. To achieve their goals, the parties used various means, such as lobbying in municipal and regional governments and influencing public opinion through hundreds of pamphlets. ${ }^{52}$ The mobilization of government entities and public opinion had one goal in the end: convincing the States General that a monopoly had to be preserved or dismantled. Eventually, decisions about Atlantic matters were made in The Hague. How the States General tried to steer a middle course between those conflicting interests is the subject of the last section of this chapter. First we will discuss how parties battled over, and lobbied for, the preservation and the reinforcement of their Atlantic interests at a local level in the Republic and in the colonial branches overseas.

\section{West India Interest on a Local Level}

After the elimination of the WIC as an active trade organization, the interests of local entrepreneurs in Atlantic shipping and trade increased greatly. In the

$5^{0} \quad$ R. Paesie, "De 'Societeyt ter Navigatie op Essequebo en annexe Rivieren'. Op en ondergang van een Zeeuwse rederij," in Alle streken van het kompas. Maritieme geschiedenis in Nederland, ed. M. Ebben, H. den Heijer and J. Schokkenbroek (Zutphen: Walburg Pers, 2010), 295-316.

$5^{1}$ Gert Oostindie, "British Capital, Industry and Perseverance versus Dutch Old School? The Dutch Atlantic and the Takeover of Berbice, Demerara and Essequibo, 1750-1815," BMGN-Low Countries Historical Review 127, no. 4 (2012): 28-55.

52 Most pamphlets can be found in the Royal Library (Knuttel Collection) in The Hague, but there are also pamphlets about Atlantic disputes in the Biblioteca Thysiana (Leiden University Library) and other collections. For an overview of pamphlets published in the first half of the seventeenth century, see Asher, A Bibliographical and Historical Essay and M. Meijer-Drees, "Goed voor de ogen. Brilmetaforiek in vroegmoderne pamfletten" in Het lange leven van het pamflet. Boekhistorische, iconografische, literaire en politieke aspecten van pamfletten 160o-19oo, ed. J. de Kruijf, M. Meijer Drees and J. Salman (Hilversum: Verloren, 2006), 129-142. 
Republic, these interests were mainly centered in the cities of Middelburg, Vlissingen, Amsterdam and Rotterdam. In addition, there were the interests of the planters and merchants in the West Indies which were not always parallel with those of the merchants, shipping companies and processors of Atlantic products in the Republic. Each city, each colony and, within these, each group, had specific interests they tried to defend - and, where and when possible, strengthen - via the various governmental entities, the WIC and the societies. The actions taken by certain groups of stakeholders, depending on the location and nature of the group, were aimed at reducing the cost of shipping and trade, to block or promote the importation of processed products, and to open up or block certain trade routes.

How important the trade with Suriname was for Amsterdam is amply illustrated by a statement made by stakeholders from the 1730s, in which the City Council was asked for support. The authors of the document did this by demonstrating which benefits Amsterdam reaped from the trade relationship with Suriname. Every year, about 35 ships sailed from Amsterdam to Suriname and back, supplying the city with 12.5 million pounds of sugar plus great amounts of coffee and cacao The trade with, and navigation to, the colony provided the city with many jobs and much income, thanks to the equipping of ships and the processing of Atlantic products. ${ }^{53}$ The Amsterdam City Council acknowledged the importance of the trade with Suriname and stimulated and facilitated it in various ways.

Amsterdam entrepreneurs were mainly interested in the import, processing and export of sugar and other plantation products, whereas the Zeelanders mainly focused on the slave trade. After the liberalization of the trade with West Africa, including the slave trade, Zeeland shipping companies fought for decades to reduce their costs by lowering their tax burden. One of the main expenses was the tax imposed by the wIC on merchantmen which sailed back and forth between the Republic and West Africa and slave ships. The tax rate was determined by the size of the ship and the duration of the journey. ${ }^{54}$ From 1730, the Zeeland shipping companies almost continuously resisted these taxes. Stakeholders in Middelburg and Vlissingen united and lobbied the city governments and the States of Zeeland for a reduction in the imposed taxes. In 1734, these actions led to an extension of the duration of journeys over which a certain sum in taxes was paid, a measure that reduced the costs for

53 J.G. van Dillen, "Memorie betreffende de kolonie Suriname," Economisch-historisch jaarboek 24 (1950): 162-167.

54 Den Heijer, Goud, ivoor en slaven, 312-314. 
shipping companies. ${ }^{55}$ However, that did not end the actions of the shipping companies. In 1750, the Zeeland shipping companies launched an initiative for the full abolition of the tax. In this, they were supported by a group of Rotterdam shipping companies with interests in the slave trade, including the trade houses of Hope, Coopstad \& Rochussen and Hudig. ${ }^{56}$ Due to the taxes of the WIC, the competitive relationship with other European merchants in the West African commodity trade, as well as the slave trade itself, had all deteriorated seriously, since non-Dutch merchants did not have to pay any taxes, meaning they could afford to pay more for African products and slaves. ${ }^{57}$ The Directors of the wIC strongly opposed the plan, however. They argued that the Zeeland and Rotterdam trade was supported by the infrastructure of the WIC in Africa. Therefore, it was only fair that those who traded with Africa paid taxes for the preservation of the necessary infrastructure. The States General agreed with the WIC and denied the request. ${ }^{58}$

Not just shipping companies, but also suppliers of these companies had significant interests in the Atlantic shipping industry. The aforementioned Amsterdam statement on trade with Suriname shows how the local middle class, from butchers to ships' carpenters, benefited from that trade relationship. For the ailing economy of Zeeland, the Atlantic trade was even more important than for Amsterdam and other cities in the province of Holland. The regulations of the Middelburgse Commercie Compagnie (MCC), for instance, stated that its merchantmen had to be equipped within the city of Middelburg - an act designed to strengthen the municipal economy. ${ }^{59}$ In 1720 , the MCC had been established for that specific purpose by a group of leading merchants, because the city's economy had suffered profoundly due to the competition of the cities in Holland since the mid-seventeenth century.60

55 Naader Reglement op het subject van de vrye Vaart op de Kust van Africa voor de Onderdaanen der Vereenigde Nederlanden (...) Gearresteert den 6 October 1734 ('s-Gravenhage: Jacobus Scheltus, 1734), Articles 3-4.

56 NL-HaNA, Staten-Generaal, 1.01.02, inv. no. 7856, Petition merchants Rotterdam to States General, 27 March 176o.

57 W.S. Unger, "Bijdragen tot de geschiedenis van de Nederlandse slavenhandel, 2. De slavenhandel der Middelburgsche Commercie Compagnie, 1732-1808," Economisch-Historisch Jaarboek 28 (1961), 1-148, 8; A. Wisse, De Commercie-Compagnie te Middelburg van haar oprichting tot het jaar 1754 (Utrecht: Schotanus \& Jens, 1933), 68.

58 NL-HaNA, Verspreide West-Indische Stukken, 1.05.06, inv. no. 24, Petition wIC to States General, 13 October 1751. Unger, "Bijdragen tot de geschiedenis," 8.

59 ZA, Archief Middelburgse Commercie Compagnie (MCC) 49, Charter of the MCC.

6o C. Reinders Folmer-van Prooijen, Van goederenhandel naar slavenhandel. De Middelburgse Commercie Compagnie 1720-1755 (Middelburg: Koninklijk Zeeuws Genootschap der Wetenschappen, 2000), 17. 
If the Board of the MCC and other shipping companies deviated from this and ordered goods for their ships from outside the province, entrepreneurs in Vlissingen en Middelburg would protest. This led, for example, to conflicts about the purchase of alcohol and meat outside of Zeeland for the supply of slave ships. ${ }^{61}$ Zeeland entrepreneurs frequently acted as an organized group during protests. In Vlissingen, Middelburg and maybe in other Zeeland cities as well, they united in so-called Merchant Committees that defended the interests of the associated entrepreneurs. When the Zeeland trade monopoly to Essequibo and Demerara was about to be dismantled, the committees protested as well. ${ }^{62}$ These protests demonstrate that the lobby for the defense of the Atlantic interests of the region took place at various levels.

Stakeholders were not always as close a group as they were in Zeeland. Within a city or region, conflicting interests could arise that would be settled via political channels. A conflict of interests that became manifest in the mideighteenth century involved the import of sugar. That conflict, which emerged between the merchants and the sugar refiners in the Republic and in the colonies, pitted the WIC against municipal governments in the States General. Initially, only coarse sugar was imported which was refined in the Republic. But the technique of sugar refining, which had been perfected in the Republic, had reached Europe and the Caribbean during the first half of the eighteenth century, which led to more and more refined sugar being imported and transshipped by Amsterdam merchants. ${ }^{63}$ The sugar refiners of Amsterdam, who expected their industry to be significantly damaged by this new development, objected to the importation of refined sugar. Merchants on St. Eustatius and in Amsterdam, who benefited from the trade in refined sugar, fought the opposed import limitation. ${ }^{64}$ Initially, the request for import limitation from the sugar refiners was not granted by the States General. However, as a concession, the import of raw sugar and the export of refined sugar was made tax-free for a period of two years in 1751. It relieved the financial burdens of the sugar

61 ZA, MCC 83, Request of Directors MCC, merchants and shipowners to burgomasters of Middelburg, 25 May 1754; MCC 108, Concept request Directors MCC to burgomasters of Middelburg, undated.

62 ZA, RvC 20, Committee of merchants of Vlissingen to States General, 24 April 1770; Ibid., Request of several merchants to States of Zeeland, 28 June 1770.

63 K. Davids, The Rise and Decline of Dutch Technological Leadership. Technology, Economy and Culture in the Netherlands, 1350-180o, 2 vols. (Leiden/Boston: Brill, 2008), 2:343-344;

L. Knappert, Geschiedenis van de Nederlandsche Bovenwindsche eilanden in de $18 e$ eeuw ('s-Gravenhage: Martinus Nijhoff, 1932), 255-257.

64 NL-HaNA, Staten-Generaal, 1.01.02, inv. no. 7822, Petition sugar refiners to States General, 6 May 1751; NA, SG 3809, Resolution 5 September 1754. 
refiners and the competitive position of sugar refined in the Republic improved. ${ }^{65}$ However, the sugar refiners were not pleased with these temporary measures. Their persistent protests eventually led to a limitation on the import of refined sugar from the Caribbean in 1756, despite the resistance of stakeholders on St. Eustatius. ${ }^{66}$ Not only Amsterdam sugar refiners but also the Rotterdam sugar refiners felt disadvantaged by the activities of the sugar traders. In the States General, they objected to the transit of lightly-taxed raw sugar to the Rhineland via Rotterdam, where a sugar processing industry had developed in a short period of time. As a result of this, Rotterdam sugar refiners were about to be pushed from the market by their colleagues from Cologne. The States General accommodated the Rotterdam sugar refiners by doubling the tax on the export of raw sugar. ${ }^{67}$

Sugar was not the only Atlantic product that caused conflicts between merchants and manufacturers. Tobacco had the same effect. In 1752, the States of Zeeland were handling a request by a group of tobacco processors from Middelburg, Vlissingen, Zierikzee and Veere. The united manufacturers asked the States for a tax increase on the import of processed tobacco, which would allow them to work in a more competitive manner. ${ }^{68}$ This request was honored. Merchants who imported processed tobacco, however, felt seriously disadvantaged and asked the States to reduce the imposed tax, but this request was denied. ${ }^{69}$ Why the requests of the merchants were denied can easily be explained. It was in the interest of the government that the employment rate in the cities remained at their current levels, and the processing of raw Atlantic products resulted in more jobs than the import of processed products.

Obviously, interests were not only represented in the Republic, but in the colonies as well. An interesting example of this is the conflict between the colonists and the Society of Suriname about the trade of the colony with North America. According to the charter of the Society, the colonists were only allowed to maintain a trade relationship with the Republic. They supplied the Republic with plantation products, whereas merchants from the Republic

65 NL-HaNA, Staten-Generaal, 1.01.02, inv. no. 3806, Resolutions 6 May, 31 August and 16 October 1751.

66 NL-HaNA, wIC, 1.05.01.02, inv. no. 451, Gentlemen Ten to States General, 4 May 1756. Knappert, Geschiedenis, 256-257.

67 C. Visser, Verkeersindustrieën te Rotterdam in de tweede helft der achttiende eeuw (Rotterdam: Benedictus, 1927), 32-33.

68 ZA, Printed resolutions States of Zeeland 1752, 16 March 1752; Collection of manuscripts 825, 20 July 1755, 9 May 1761 and 20 September 1762.

$69 \quad$ ZA, Printed resolutions States of Zeeland 1754 and 1755, 11 March 1754 and 14 August 1755. 
would provide the colonists with the necessary European products. That symbiotic relationship between colony and homeland would soon appear to be unworkable. For the import of sufficient draught animals and food and the export of molasses (a residual product of sugar that was not shipped to the Republic) the colonists depended heavily on the regional trade. Initially, they had a trade relationship with Barbados, but at the end of the seventeenth century it shifted to trade with North American colonies. ${ }^{70}$ That trade was illegal, but was often condoned. A long-term conflict arose about the legalization of the trade with North America between the colonial government, which represented the interests of the Society of Suriname and the planters. The main opponent of the imposed trade ban was the influential planter Samuel Nassy. Eventually, colonists succeeded in legalizing the trade with North America. As of 1704 , it was permitted under certain conditions and on the payment of a tax. ${ }^{71}$

\section{Conclusion}

In this final section, we will return to the question of whether or not the Republic had a West India Interest. Van der Voort thought that there was not one, and was supported in this view by Piet Emmer. Emmer states that the British plantation colonies in the Caribbean were considered "darlings of empire" in the metropole. All plantation products produced on the islands had to be shipped to Great Britain according to the Acts of Navigation introduced in the seventeenth century, where they were processed into end products and subsequently sold on the domestic and foreign markets. Processed and unprocessed Atlantic products from non-British colonies were barred from Great Britain. That mercantilist policy was supposedly reinforced in the course of the eighteenth century by the lobby of stakeholders in the West Indian plantations and trade. The Republic did not have such protective constructions, due to which, as Emmer states, it was impossible to have a common West India Interest such as existed in Great Britain. ${ }^{72}$ His observation is correct insofar as

$70 \quad$ See Karwan Fatah-Black's chapter in this volume.

71 J.A. Schiltkamp and J. Th. de Schmidt, eds., West Indisch Plakaatboek. Plakaten, ordonnantiën en andere wetten uitgevaardigd in Suriname, 1667-1761 2 vols., (Amsterdam: Emmering, 1973), 1:253-255; Fatah-Black, Suriname and the Atlantic World (unpublished PhD diss., diss., University of Leiden, 2013).

72 P.C. Emmer, "The Dutch and the Atlantic Challenge, 1600-180o," in A Deus ex Machina Revisited. Atlantic Colonial Trade and European Economic Development, ed. P.C. Emmer, O. Pétré-Grenouilleau and Jessica Vance Roitman (Leiden/Boston: Brill, 20o6), 176. 
it concerns a homogenous group that rallied behind one common interest, which in fact did not happen in the Republic. But O'Shaughnessy demonstrated that this communal cause only existed briefly in Great Britain. Moreover, "the size of the West India lobby (...) was not sufficient to explain their influence upon government." ${ }^{\prime 3}$ The influence of such interest groups was often greatly exaggerated in the past. ${ }^{74}$ When, in the late eighteenth century, an abolitionist movement emerged within and outside of the parliament, the West Indian lobbyists did not succeed in providing sufficient counterweight to it, and eventually they had to accept that slavery would be abolished.

It is clear that there is much to criticize about the classic belief that Great Britain has known a politically influential, convergent West Indian interest group. The British government did take measures to protect its West Indian interests, but they were part of a much wider mercantilist policy that was supposed to promote their own trade and industry and to increase the income of the state. Since the seventeenth century, Great Britain had a Board of Trade and Plantations, managed by the Privy Counsel. The decentralized Republic did not have such a central organ, but the necessity to protect the Atlantic interest was widely acknowledged. A mercantilist policy was not viewed as the appropriate means for this protection, however. Unlike Great Britain, the Republic had neither extensive plantation colonies nor a large internal market to which tropical products could be sold. Moreover, the States General always had to take into account the West Indian interests of the various cities and provinces. This required the necessary persuasion and compromise politics that involved a lot of trial and error. These actions of the States General, in particular, demonstrate that there was a widely supported West India Interest that suited the decentralized nature of the Republic.

Initially, the States General greatly influenced the development of private trade and shipping in the Atlantic based on political-military motives. When those motives were no longer relevant and the economic interests of the Republic in the Atlantic became increasingly important, the States General supported those interests in various ways. Firstly, by offering military assistance. The WIC was, unlike her sister organization, the Dutch East India Company (voc) in Asia, unable to defend Dutch interests in the Atlantic. As of the mid-seventeenth century, war fleets were dispatched to Africa and America, trade ships convoyed from and to the Caribbean, State troops deployed in

73 O'Shaughnessy, "The Formation," 93.

74 J.D. Stewart, British Pressure Groups: Their Role in Relation to the House of Commons (Oxford: Oxford University Press, 1958), 238. 
plantation colonies, and money made available for defense purposes. All this happened, of course, within the limited financial resources the States General had. More difficult to deal with were the often-opposed Atlantic interests of the cities and regions within the Republic. On paper, every voting city in a province and every province in the States General had an equal vote, but in practice the vote of the economically strongest party would always be worth much more. Even in the early modern era, the unwritten rule was "he who pays the piper calls the tune." Thus, the political battle fought in the States General regarding the Atlantic interests was often settled to the advantage of the merchants and entrepreneurs of Amsterdam. An example of this was the discussion regarding free trade to Brazil. However, to make sure that the discrepancies would not get too extensive, the States General, which was dominated by the representatives of Holland, also had to satisfy the Zeelanders in certain situations. This was done, for instance, by abolishing the wIC monopoly on the slave trade, which helped Middelburg and Vlissingen to obtain a leading position in this trade. The routes to the plantation colonies of Demerara and Essequibo, despite the formal abolition of the Zeeland monopoly in 1770, also remained mainly in the hands of the Zeeland merchants. In contrast, Amsterdam, and, to a lesser extent, Rotterdam, almost fully controlled the import of plantation products. The processing of sugar and tobacco mainly took place in these two cities. The assumption of Van der Voort and Emmer that the Republic did not have a West India interest, is, in my opinion, a misconception. It existed, but its makeup differed from that of Great Britain in some respects. The Atlantic interests were significant at local and regional levels, especially in Holland and Zeeland, and were strongly defended by the various parties in the States General. Moreover, these interests grew more and more essential. While the economy of the Republic began to stagnate around the mid-eighteenth century, its share of the Atlantic trade nevertheless increased due to the growing demand in Europe for sugar, coffee, tobacco and other plantation products. ${ }^{75}$ Every year, dozens of ships sailed to African and American port cities to sell Dutch products, buy slaves and load plantation products. In addition, many plantation products were imported into the Republic indirectly via French and British ports. The sugar and tobacco industry provided jobs to thousands of people in Amsterdam and

75 J.L. van Zanden and A. van Riel, Nederland 1780-1914: staat, instituties en economische ontwikkeling (Amsterdam: Balans, 200o), 31 Table 1.1; J. de Vries, "The Dutch Atlantic Economies," in The Atlantic Economy during the Seventeenth and Eighteenth Centuries: Organization, Operation, Practise and Personnel, ed. P.A. Coclanis (Columbia: University of South Carolina Press, 2005), 1-29, 18-21. 
Rotterdam. ${ }^{76}$ This development led more and more people in the Republic to invest capital in West Indian plantations. In the period of $1753^{-1794}$, Dutch investors poured an estimated 80 million guilders in plantations, a quarter of which was invested in non-Dutch colonies. Over 80 percent of that money originated from Amsterdam investors. The Amsterdam financial crisis of 1773 that affected many investors in plantations did not end the growth of the Atlantic trade and the shipping of the Republic. ${ }^{77}$ Only after the French and the patriots had dissolved the old Republic in 1795 did the tide turn.

76 In 1740, approximately 165 sugar refineries with an average of 20 workers per factory and an unknown number of small sugar processing industries were operating in the Republic, most of them in Amsterdam. This number remained relatively stable until the end of the eighteenth century. Unfortunately there are no reliable figures for the tobacco industry. J. de Vries and A. van der Woude, Nederland 1500-1815. De eerste ronde van moderne economische groei (Amsterdam: Balans, 1995), 386-388; C. Lesger, "Stagnatie en stabiliteit. De economie tussen 1730 en 1795 " in Geschiedenis van Amsterdam. Zelfbewuste stadstaat, 1650-1813, ed. W. Frijhoff and M. Prak , 4 vols., (Amsterdam: sun, 2005), 2-2:240-244.

77 Van de Voort, De Westindische plantages, 264-265, appendices XVIII and XIX. 